\title{
A comparative study on the effect of online verses offline teaching on burnout among the teaching fraternity
}

\author{
Mrs. Vinatha $\mathrm{K}^{\mathbf{1}}$, Mr. Naresh $\mathbf{M}^{2}$, Miss. Amora Monteiro ${ }^{3}$, Miss. Srujani ${ }^{4}$, Miss. Shreya $\mathbf{M}^{5}$ \\ ${ }^{1}$ Associate Professor, Department of Psychology, St Agnes College (Autonomous), Mangalore. \\ ${ }^{2}$ HOD of Humanities, SDM Law College, Mangalore \\ ${ }^{3}$ Lecturer, Department of Psychology, St. Agnes College (Autonomous), Mangalore. \\ ${ }^{4,5}$ III BA. St. Agnes college (Autonomous), Mangalore
}

\begin{abstract}
Burnout is a topic which is frequently being used among the employees in the present generation. A term which was unheard earlier has now become a part and parcel of the workforce. People now and then keep on saying I feel burnt out. Due to the increasing number of cases of burnout, the research paper is related to finding the level of burnout in the respondents. As we now have blended mode of education, this is a comparative study on the level of burnout with reference to online and offline classes among the teaching fraternity.

For this study the researcher has made use of the questionnaire developed by Christina Maslach on burnout. This questionnaire consists of 15 questions where the respondents have to mark their preferences based on the five alternatives. The sample consists of 50 educationalists from various institutes. The Hypothesis framed by the researcher is that the level of burnout will be greater during online classes when compared to offline classes.
\end{abstract}

Keywords: 1Burnout,2 Blended mode, 3 Online and 4 Offline classes.

\section{INTRODUCTION}

Burnout is a state of negative feeling experienced by an individual. Burnout is a burning topic of the day which is receiving a lot of attention presently. During burnout the person feels drained, stressed, physically and mentally weak, they are not able to meet demands of the work place. This leads to stress and the person in turn loses interest, motivation and liking to do any job. This is a vicious circle because this in turn will decrease the productivity and also affect the performance at work as well as family and social life. The person may be having more of negative thoughts than positive. This may come in gradually, unless and until kept under check and control it may lead to sever burnout or a major break down which may be irreparable.[1] The term Burnout was coined by Herbert Freudenberger, an American psychologist in the year 1970. He used this phrase to refer to medical professionals, but it is now used by everyone.

According to ICD 11, burnout is an occupational phenomena rather than a medical illness.

[2]Burnout is characterised as follows in ICD 11:

"Burnout is a syndrome conceptualized as resulting from chronic workplace stress that has not been successfully managed. It is characterized by three dimensions:

- $\quad$ Feeling of energy depletion or exhaustion;

- Increased mental distance from one's job, or feelings of negativism or cynicism related to one's job; and

- $\quad$ Reduced professional efficacy.

Burnout refers specifically to phenomena in the occupational context and should not be applied to describe experiences in other areas of life".

\subsection{The Objectives of this study is to:}

- $\quad$ Assess your level of burnout.

- $\quad$ Compare the level of burnout during online and offline classes.

- $\quad$ Preventive measures for dealing with burnout.

1.3 The Methodology adopted is:

This is a cross sectional descriptive study. The study adopted the questionnaire developed by Christina Maslach. It consists of 15 questions with 5 alternatives to choose from. The alternatives are Not at all, Rarely, Sometimes, Often and Very often 


\section{International Advanced Research Journal in Science, Engineering and Technology \\ Impact Factor 7.105 Vol. 9, Issue 1, January 2022 \\ DOI: 10.17148/IARJSET.2022.9144}

\subsection{Sample}

The sample consists of 50 educationalists from various institutes irrespective of the gender to which they belong. The teachers taken as sample have used the blended mode of teaching.

\subsection{Hypothesis}

The hypothesis adopted for the study is that the level of burnout is greater during online classes when compared to offline classes.

1.6 Variables: Independent Variable- In the present study the independent variable is the questionnaire on burnout. Dependent variable- They are the responses given by the respondents. The responses are dependent on the mode of classes that were being taken that is online / offline.

\subsection{Causes of Burnout}

There may be varied reasons for a person to fall a prey to burnout. Some of them could be, being over worked, undervalued, stressful work situation, lifestyle, personality, over demanding work situation, always working under pressure, workload, lack of supportive people, too many responsibilities, colleagues and extreme commitment leading to no time for oneself.

Physical signs and symptoms of burnout include constant tiredness, exhaustion, frequent illness, poor sleep, and a change in eating habits.

Emotional - Sense of failure, helplessness, defeated, lonely, lack of motivation, negative thoughts, unable to cope.

Behavioural - Withdrawal, isolation, procrastination, displacement, escaping from responsibility, cynical.

\subsection{Tips to handle burnout}

- $\quad$ Seek support and help from others

- Use relaxation techniques

- $\quad$ Exercise regularly

- $\quad$ Sleep well

- $\quad$ Change your attitude towards the job.

- $\quad$ Practice work life balance

- $\quad$ Take a break

- Have hobbies

- Healthy diet

\subsection{Suggestion for employers to reduce the level of burnout}

- $\quad$ Flexible working conditions

- $\quad$ Caring about the wellbeing of their employees

- Restrict responsibilities

- $\quad$ Conduct mindful sessions / relaxation sessions

- Have outings and picnics (not during a pandemic)

- $\quad$ Encourage and support rather than putting down the person

- Give sufficient work and not over work and not burden the person.

\section{REVIEW OF LITERATURE}

- [3] Abenavoli, et al. (2013) investigated the protective effects of mindfulness against burnout among educators in a sample of 64 educators. The results of the study indicated that educators' mindfulness had strong, consistent negative associations with three widely-studied components of burnout: emotional exhaustion, depersonalisation, and low personal accomplishment. The link between mindfulness and burnout was partially explained by affect, sleep-related impairment, and daily physical symptoms. In addition, the protective effect of mindfulness was most pronounced among more stressed and more ambitious educators.

- [4] Sasa, Boroş \& Bonchiş (2011) examined Aspects of the burnout syndrome within the teaching staff among 162 Romanian teachers. The findings revealed that the level of education at which the teaching activity is carried out (pre-school or elementary in the case of the sample group under study) has a significant impact on the degree of fatigue experienced by the teaching staff, which is most evident at the level of perceived emotional exhaustion. 


\section{International Advanced Research Journal in Science, Engineering and Technology \\ Impact Factor 7.105 Vol. 9, Issue 1, January 2022 \\ DOI: $10.17148 / I A R J S E T .2022 .9144$}

- [5] Adekola (2010) explored the Gender differences in the experience of work burnout among university staff among 1040 respondents (549 male and 491 female). Results of the study indicated that there is no difference in the levels of emotional exhaustion and depersonalisation of both male and female staff. It was also found that female staff experienced higher level of reduced personal accomplishment than their male counterparts.

\section{RESULTS AND DISCUSSION}

Table I showing the total number of respondents experiencing burnout their scores and interpretation during online and offline classes.

\begin{tabular}{|c|c|c|c|c|c|c|c|c|c|}
\hline \multicolumn{2}{|l|}{$15-18$} & \multicolumn{2}{|l|}{$19-32$} & \multicolumn{2}{|l|}{$33-49$} & \multicolumn{2}{|l|}{$50-59$} & \multicolumn{2}{|l|}{$60-75$} \\
\hline $\begin{array}{l}\text { No s } \\
\text { burnou }\end{array}$ & gn of & $\begin{array}{l}\text { Little } \\
\text { burno }\end{array}$ & ign of & $\begin{array}{l}\text { Maybe } \\
\text { of burn }\end{array}$ & $\begin{array}{l}\text { at risk } \\
\text { ut }\end{array}$ & $\begin{array}{l}\text { Sever } \\
\text { burno }\end{array}$ & isk of & $\begin{array}{l}\text { Very } \mathrm{s} \\
\text { of bur }\end{array}$ & $\begin{array}{l}\text { ver risk } \\
\text { out }\end{array}$ \\
\hline Online & Offline & online & offline & Online & offline & online & offline & online & Offline \\
\hline- & 4 & 27 & 26 & 19 & 17 & 4 & 3 & - & - \\
\hline
\end{tabular}

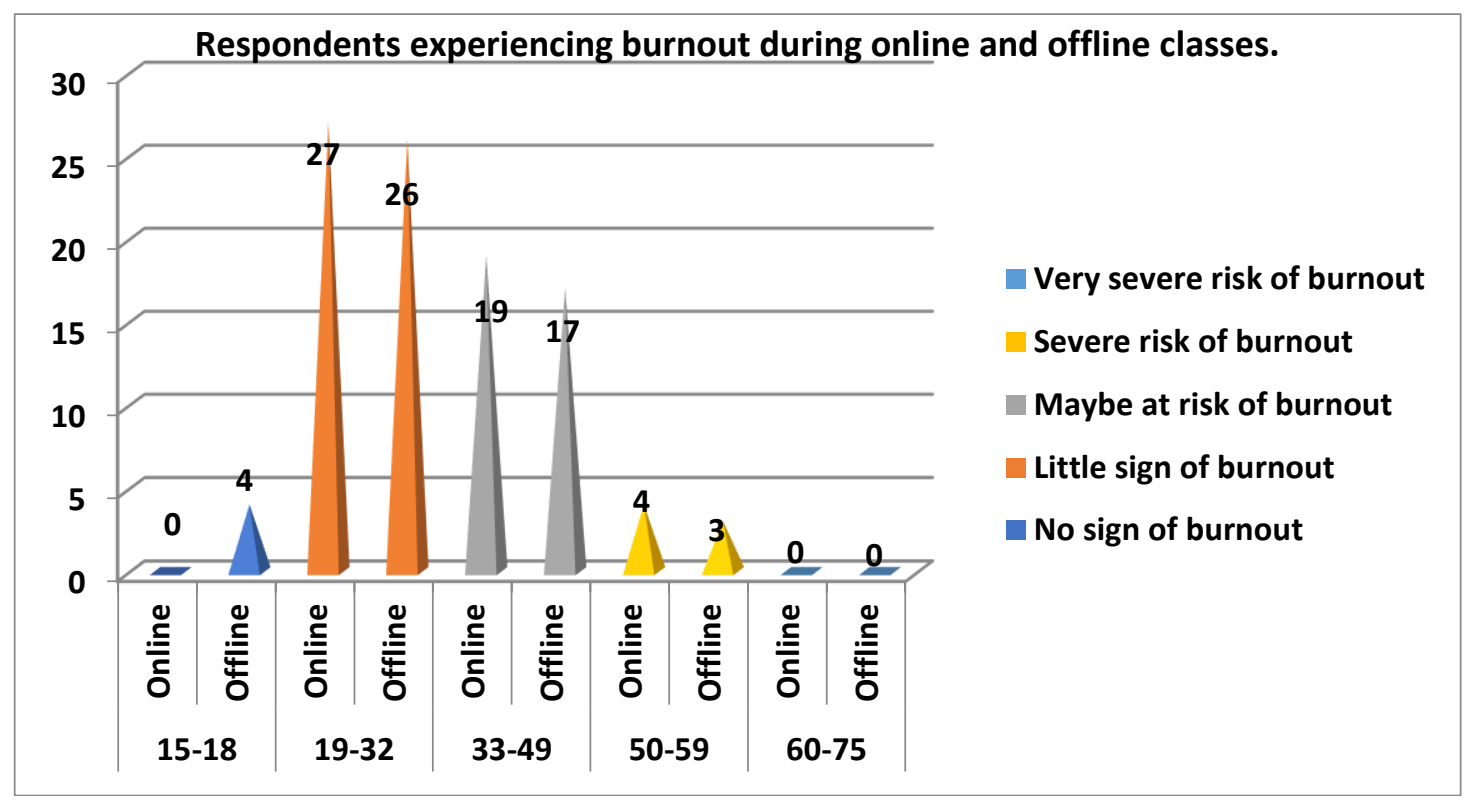

Chart .1. Respondents experiencing burnout during online and offline classes

Table 1 shows the scores and interpretation of the respondents in online and offline mode of teaching. Even a single respondent has not reported as having "No sign of burnout" during online class, but 4 respondents have reported no sign of burnout during offline classes. 27 respondents have reported "Little sign of burnout" during online classes while only 26 respondents have reported burnout during offline classes.19 respondents have said that they "May be at risk of burnout" during online classes and only 17 reported during offline classes. Regarding "Severe risk" 4 have reported during online while only 3 have reported during offline. None of the respondents have reported "Very severe risk of burnout" So, in all the 4 categories, most respondents find offline classes better than online classes which were more strainfull and stress provoking than offline classes. The hypothesis formulated at the beginning of the study is accepted as the level of burnout is greater during online classes than offline classes. As the calculated $t$ is 0.13 which is lesser than the tabulated $t_{2}$ which is 2.67 .

Data Analysis - Table II shows the statistical calculation of data

\begin{tabular}{|l|l|l|l|l|}
\hline SUBJECTS & $\begin{array}{l}\text { ONLINE } \\
\text { SCORE }\end{array}$ & INTERPRETATION & $\begin{array}{l}\text { OFFLINE } \\
\text { SCORE }\end{array}$ & INTERPRETATION \\
\hline 'A & 59 & SEVERE RISK & 51 & SEVERE RISK \\
\hline $\mathrm{B}$ & 22 & LITTLE SIGN & 23 & LITTLE SIGN \\
\hline $\mathrm{C}$ & 25 & LITTLE SIGN & 25 & LITTLE SIGN \\
\hline $\mathrm{D}$ & 25 & LITTLE SIGN & 25 & LITTLE SIGN \\
\hline
\end{tabular}


International Advanced Research Journal in Science, Engineering and Technology

Impact Factor $7.105 \div$ Vol. 9, Issue 1, January 2022

DOI: 10.17148/IARJSET.2022.9144

\begin{tabular}{|c|c|c|c|c|}
\hline $\mathrm{E}$ & 23 & LITTLE SIGN & 31 & LITTLE SIGN \\
\hline $\mathrm{F}$ & 40 & MAY BE AT RISK & 40 & MAY BE AT RISK \\
\hline $\mathrm{G}$ & 36 & MAY BE AT RISK & 31 & LITTLE SIGN \\
\hline $\mathrm{H}$ & 34 & MAY BE AT RISK & 35 & MAY BE AT RISK \\
\hline $\mathrm{I}$ & 35 & MAY BE AT RISK & 34 & MAY BE AT RISK \\
\hline $\mathrm{J}$ & 31 & LITTLE SIGN & 32 & LITTLE SIGN \\
\hline $\mathrm{K}$ & 21 & LITTLE SIGN & 22 & LITTLE SIGN \\
\hline $\mathrm{L}$ & 30 & LITTLE SIGN & 26 & LITTLE SIGN \\
\hline M & 29 & LITTLE SIGN & 35 & MAY BE AT RISK \\
\hline $\mathrm{N}$ & 34 & MAY BE AT RISK & 19 & LITTLE SIGN \\
\hline $\mathrm{O}$ & 32 & LITTLE SIGN & 26 & LITTLE SIGN \\
\hline $\mathrm{P}$ & 33 & MAY BE AT RISK & 34 & MAY BE AT RISK \\
\hline $\mathrm{Q}$ & 41 & MAY BE AT RISK & 38 & MAY BE AT RISK \\
\hline $\mathrm{R}$ & 37 & MAY BE AT RISK & 26 & LITTLE SIGN \\
\hline$S$ & 38 & MAY BE AT RISK & 38 & MAY BE AT RISK \\
\hline $\mathrm{T}$ & 33 & MAY BE AT RISK & 22 & LITTLE SIGN \\
\hline $\mathrm{U}$ & 27 & LITTLE SIGN & 25 & LITTLE SIGN \\
\hline $\mathrm{V}$ & 47 & MAY BE AT RISK & 45 & MAY BE AT RISK \\
\hline $\mathrm{W}$ & 32 & LITTLE SIGN & 17 & NO RISK \\
\hline $\mathrm{X}$ & 28 & LITTLE SIGN & 25 & LITTLE SIGN \\
\hline $\mathrm{Y}$ & 53 & SEVERE RISK & 50 & SEVERE RISK \\
\hline $\mathrm{Z}$ & 32 & LITTLE SIGN & 33 & MAY BE AT RISK \\
\hline AA & 54 & SEVERE RISK & 53 & SEVERE RISK \\
\hline $\mathrm{AB}$ & 26 & LITTLE SIGN & 26 & LITTLE SIGN \\
\hline $\mathrm{AC}$ & 38 & MAY BE AT RISK & 40 & MAY BE AT RISK \\
\hline $\mathrm{AD}$ & 20 & LITTLE SIGN & 15 & NO RISK \\
\hline $\mathrm{AF}$ & 38 & MAY BE AT RISK & 36 & MAY BE AT RISK \\
\hline $\mathrm{AG}$ & 48 & MAY BE AT RISK & 33 & MAY BE AT RISK \\
\hline $\mathrm{AH}$ & 41 & MAY BE AT RISK & 41 & MAY BE AT RISK \\
\hline $\mathrm{AI}$ & 26 & LITTLE SIGN & 31 & LITTLE SIGN \\
\hline $\mathrm{AJ}$ & 27 & LITTLE SIGN & 29 & LITTLE SIGN \\
\hline $\mathrm{AK}$ & 51 & SEVERE RISK & 37 & MAY BE AT RISK \\
\hline $\mathrm{AL}$ & 29 & LITTLE SIGN & 28 & LITTLE SIGN \\
\hline AM & 25 & LITTLE SIGN & 23 & LITTLE SIGN \\
\hline $\mathrm{AN}$ & 30 & LITTLE SIGN & 31 & LITTLE SIGN \\
\hline $\mathrm{AO}$ & 22 & LITTLE SIGN & 36 & MAY BE AT RISK \\
\hline AP & 36 & MAY BE AT RISK & 34 & MAY BE AT RISK \\
\hline $\mathrm{AQ}$ & 20 & LITTLE SIGN & 39 & MAY BE AT RISK \\
\hline $\mathrm{AR}$ & 23 & LITTLE SIGN & 20 & LITTLE SIGN \\
\hline AS & 30 & LITTLE SIGN & 30 & LITTLE SIGN \\
\hline $\mathrm{AT}$ & 22 & LITTLE SIGN & 24 & LITTLE SIGN \\
\hline $\mathrm{AU}$ & 36 & MAY BE AT RISK & 30 & LITTLE SIGN \\
\hline $\mathrm{AV}$ & 34 & MAY BE AT RISK & 39 & MAY BE AT RISK \\
\hline AW & 39 & MAY BE AT RISK & 37 & MAY BE AT RISK \\
\hline $\mathrm{AX}$ & 28 & LITTLE SIGN & 28 & LITTLE SIGN \\
\hline AY & 32 & LITTLE SIGN & 33 & MAY BE AT RISK \\
\hline Total & 1652 & & 1581 & \\
\hline Mean & 33.04 & MAY BE AT RISK & 30.54 & LITTLE SIGN \\
\hline
\end{tabular}

STATISTICAL ANALYSIS

$\sum \mathrm{d}=61$

$\sum \mathrm{d}^{2}=2205$

$\mathrm{d}=\frac{\sum \mathrm{d}}{\mathrm{n}}=\frac{61}{50}=1.22$

$\mathrm{sd}=\sqrt{\frac{1}{\mathrm{n}-1}\left[\sum \mathrm{d}^{2}-\mathrm{n}\left(\mathrm{d}^{-}\right)^{2}\right]}$ 


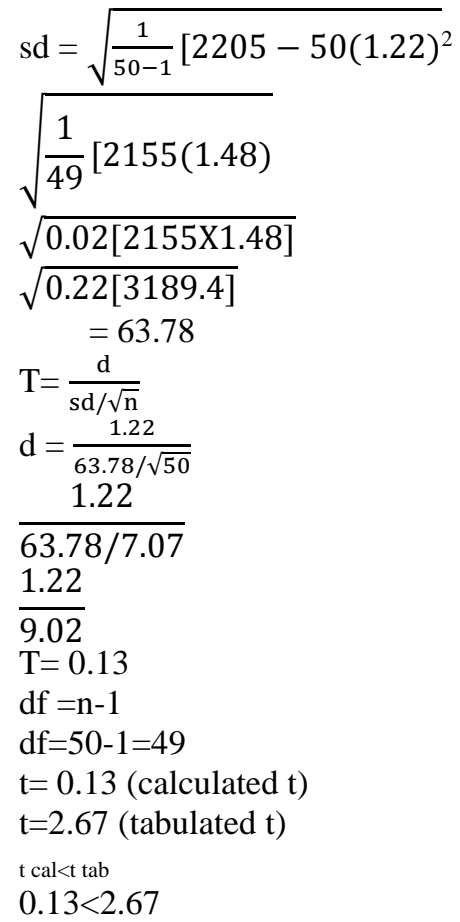

INTERPRETATION:_Since the calculated $\mathrm{t}$ is lesser than the tabulated $\mathrm{t}$, the hypothesis is proved in affirmation that the level of burnout is greater during online classes than offline classes.

\section{CONCLUSION}

Burnout is present and will continue in greater degree if left unchecked. The study revealed that majority of the respondents faced burnout situation in an online class than in the offline mode. Individuals with high degree of burnout need to be vigilant and take the matter seriously and be careful in order to avoid being physically and mentally affected. Until and unless organizations and managements plan out ways and strategies to make their employees being satisfied with their work, the problem of burnout will not be resolved.

\section{REFERENCES}

[1]https://www.ncbi.nlm.nih.gov/books/NBK279286/

[2] https://www.who.int/news/item/28-05-2019-burn-out-an-occupational-phenomenon-international-classification-ofdiseases

[3]Abenavoli, etal 2013/01/01 The protective effects of mindfulness against burnout among educators Emotional_Competence_Identifying_Risk_and_Protective_Factors_in_Relation_to_Classroom_Efficacy_and_Burnout. VL - ISSN 0262-4087 JO - The Psychology of Education Review,

[4]AU - Boros, etal (2011) Aspects of the burnout syndrome within the teaching staff VL - 11

DO - 10.1016/j.sbspro.01.074 JO - Procedia - Social and Behavioral Sciences

[5] Adekola, Bola PY - 2010/06/01SP - T1 - Interferences between work and family among male and female executives in Nigeria VL - 4 JO - African journal of business management

[6] Melinda Smith, M.A., Jeanne Segal, Ph.D., and Lawrence Robinson. (2021) Burnout Prevention and Treatment. https://www.helpguide.org/articles/stress/burnout-prevention-and-recovery.htm [7] Retrieved from https://www.researchgate.net/publication/268146185_Teachers'_Stress_and_Social-

[8]https://core.ac.uk/download/pdf/82257729.pdf

https://academicjournals.org/journal/AJBM/article-full-text-pdf/E64B91023543

[9] InformedHealth.org [Internet]. Cologne, Germany: Institute for Quality and Efficiency in Health Care (IQWiG); 2006-. Depression: What is burnout? [Updated 2020 Jun 18]. Available from: https://www.ncbi.nlm.nih.gov/books/NBK279286/

[10]https://www.mayoclinic.org/healthy-lifestyle/adult-health/in-depth/burnout/art-20046642

[11]https://www.drugs.com/mca/job-burnout-how-to-spot-it-and-take-action

V S P RAO. (2010). Organizational Behaviour. New Delhi, Excel Books. 